\title{
THE CURRENT STATE OF REHABILITATION OF UKRAINIAN CITIZENS
}

\section{OBECNY STAN REHABILITACJI LECZNICZEJ OBYWATELI UKRAINY}

\author{
Ihor Mysula $^{1(\mathrm{~A}, \mathrm{~B}, \mathrm{D}, \mathrm{E}, \mathrm{F})}$, Yuriy Mysula ${ }^{1(\mathrm{~A}, \mathrm{~B}, \mathrm{D}, \mathrm{F})}$, Nataliya Sydliaruk ${ }^{1(\mathrm{~A}, \mathrm{~B}, \mathrm{E}, \mathrm{F})}$ \\ ${ }^{1}$ I. Horbachevsky Ternopil State Medical University, Ukraine
}

Authors' contribution Wkład autorów: A. Study design/planning zaplanowanie badań B. Data collection/entry zebranie danych C. Data analysis/statistics dane - analiza i statystyki D. Data interpretation interpretacja danych E. Preparation of manuscript przygotowanie artykułu F. Literature analysis/search wyszukiwanie $i$ analiza literatury G. Funds collection zebranie funduszy
Tables: 0

Figures: 0

References: 13

Submitted: 2017 Jul 31

Accepted: 2017 Nov 11

\section{Summary}

The system of rehabilitation in Ukraine is ineffective presently, because it does not follow any international experience and most physicians and instructors involved in physical therapy do not possess updated knowledge about functional anatomy and the principles of restoration of functions. All measures referred to "rehabilitation" are in fact only a sum of actions, "ritual" in their character: the use of medicine that has no effect on the restoration of functions; physical exercises without specified, time-limited rehabilitation goals; the patient's "physical activity" in the stages of rehabilitation, which, in fact, repeats the actions of the previous stage; cyclic iteration of the above-mentioned step-by-step actions without real prospects for further recovery. Further, there is lack of specialists in rehabilitation in Ukraine, which has only now started to actively create a modern system of rehabilitation. Since August 2016, the National Classification of Occupations has given new names to professions, including: a doctor of physical and rehabilitation medicine, an ergotherapist and a physical therapist. The current regulatory framework is being reorganized so as to create jobs in health care facilities for specialists in medical and physical rehabilitation. Finally, the Ministry of Healthcare of Ukraine initiated the implementation of the International Classification of Functioning, Disability and Health in the Ukrainian rehabilitation.

Keywords: rehabilitation, Ukraine, disability, training of rehabilitation specialists, reformation of the rehabilitation system

\section{Streszczenie}

Obecny system rehabilitacji na Ukrainie nie jest doskonały i mało efektywny, ponieważ nie korzysta z doświadczenia międzynarodowego, a lekarze i fizjoterapeuci, instruktorzy gimnastyki leczniczej w większości faktycznie nie posiadają nowoczesnej wiedzy z zakresu anatomii funkcjonalnej i zasad odnowy funkcjonalnej. Wszystkie środki zwane „rehabilitacją” faktycznie mają charakter „rytualny”: stosowanie leków, które nie mają żadnego wpływu na odnowę funkcjonalną; ćwiczenia fizyczne bez kształtowania szczególnych, ograniczonych czasowo celów rehabilitacyjnych; „przesunięcie” pacjenta „w etapach” rehabilitacji, które w rzeczywistości powtarzają działania z poprzedniego etapu; cykliczne powtarzanie poprzez wykorzystanie wspomnianego działania z faktycznym brakiem perspektywy odnowy. Na Ukrainie brakuje specjalistów od rehabilitacji. Obecnie Ukraina zaczęła aktywnie tworzyć nowoczesny system rehabilitacji. Od sierpnia 2016 w krajowej klasyfikacji zawodów pojawiły się nowe nazwy zawodów, takie jak "lekarz medycyny fizykalnej i rehabilitacji”, "ergoterapeuta" i „fizjoterapeuta”, reorganizuje się obecne ramy regulacyjne, odbywaja się aktywne szkolenia nowych pracowników w zakresie rehabilitacji, wprowadza się Międzynarodową Klasyfikację Funkcjonowania, Ograniczenia Działalności i Zdrowia.

Słowa kluczowe: rehabilitacja, Ukraina, niepełnosprawność, szkolenie specjalistów rehabilitacyjnych, reforma systemu rehabilitacji

\section{Introduction}

The main goal of social development in every country is to maintain high level of citizens' health and to prevent the development of diseases and disabilities. It is because health is of paramount importance, as indicated in the system of universal values. Accordingly, human health is considered an important indicator and it holds the first position in the indices of social development of any country in the world.

\section{Aim of the work}

To study the current state of rehabilitation in Ukraine and to present the directions of its`reformation. 


\section{Brief description of the status of knowledge}

There are about 3 million people with disabilities and 12 million retirees and patients with chronic diseases in Ukraine. Cardiovascular and cerebrovascular diseases are the cause of almost two thirds of all deaths and one third of the disabilities. There are about 107,000 strokes, 50,000 cases of myocardial infarction, and 4,000 acquired heart defects registered annually in Ukraine and more than 3,500 newborn children with congenital heart disease. The mortality rate for cerebrovascular diseases has increased by $18.2 \%$ for the past 15 years and currently affects 223.1 people per 100000 population [1].

Besides, there is an increasing number of diseases that cause a decrease of life expectancy, higher mortality, disability, traumatic injuries as well as deterioration of working conditions or living in ecologically harmful areas. All these are objective factors that require taking decisive and extraordinary steps aimed at keeping public health. Therefore, the implementation of complex medical rehabilitation measures to support the quality of life of patients with chronic disease or with post-traumatic illnesses, disabled people, children with disabilities, elderly people are of paramount importance.

The military conflict in the Donbass region significantly complicated the situation of proper health provision. According to different sources, about 50000 of Ukrainian soldiers are involved in the armed conflict in the east of Ukraine today, and about 9000 military serviceman since the beginning of the Anti-Terrorist Operation (in 2014) have been injured [2]. Almost 98\% of soldiers "may require highly qualified psychological help", as suggested by the international estimates and numerous studies $[3,4,5]$.

Psychologists consider that in case of inadequate treatment, post-military symptoms do not just return they tend to intensify. Soldiers who experienced the horrors of war often suffer from insomnia, lack of emotions or irritability. In order help them adapt to normal and peaceful life, such patients have to undergo specialized treatment. Psychologists note that, after having suffered terrible events, people do not want to contact with others because, in their opinion, time will cure everything. They usually keep everything inside themselves. In this way, as doctors indicate, military actions are decreasing the level of psychological health and the need to treat such persons is increasing day to day [2].

Having in mind the fact that $90 \%$ of patients need medical rehabilitation, it seems strange that the problem of establishment and running a thorough system of medical rehabilitation during the last 20 years has not been noticed in the medical field. In fact, it was mentioned only in programmes of social, labour and professional rehabilitation of the disabled in the context of providing them with medical products. At the same time, the main direction of medical rehabilitation is to restore the patients' health, which should appear right after emergency treatment as its consequent stage.

Particular attention needs to be paid to organizing a medical rehabilitation system in rural areas.

Why the system of rehabilitation is ineffective in Ukraine presently? During the past 20 years, the world has fundamentally changed the idea of how human function should be restored after damage. These changes have not been implemented into the medical practice in Ukraine. The national rehabilitation system does not follow the principles of setting goals and an individual approach to each patient. Most physicians and instructors involved in physical therapy do not possess updated knowledge about functional anatomy and the principles of restoration of functions $[6,7,8]$. The absence of the system has resulted in a stereotype of the need for "periodic hospitalization" that substitutes for "rehabilitation", during which only drug therapy is conducted. This ensures the existence of a large number of stationary beds that require material and medical resources and, accordingly, doctors' employment, which proves that they are needed. All measures called "rehabilitation" are in fact only of "ritual" character: the use of medicine that has no effect on the restoration of functions; use of physical exercises without the formation of specific, time-limited rehabilitation goals; "movement" of the patient in the stages of rehabilitation, which, in fact, repeats the actions of the previous stage; cyclic iteration of the above-mentioned step-by-step actions without real prospects of further recovery [8,9].

Understanding of the term "disability" in Ukraine does not correspond to the modern internationally agreed understanding of the concept as limitations of life and its functioning. Such was the conclusion issued by the World Health Organization mission, who came to investigate the problem in December 2015 [10]. The mission visited a number of medical institutions and centres of social protection in Kyiv to understand the system of rehabilitation assistance, social aspects of rehabilitation and the living conditions of people with disabilities in the country.

In addition, the World Health Organization mission for rehabilitation stated in its report that rehabilitation services in Ukraine are traditionally provided in the resort environment, while the legislation of rehabilitation in Ukraine is fragmented and divided in coordination between different authorized ministries and organizations. In addition, the WHO experts came to the conclusion that Ukrainian rehabilitation staff and personnel do not follow appropriately the International and European standards [10]. 
It means that the human being is not at the centre of the rehabilitation process. If a person with spinal injury needs to be rehabilitated, then it has to be understood that he/she is likely to be paralyzed, have problems with the coordination and disorders of cardiovascular, respiratory, digestive and other systems. Then, such a person needs help that does not necessarily relate to the type of disease, but functional disorders. The patient must learn not only to move, but also to eat, dress and so on. Can a doctor do this? Definitely not, as it requires different specialists.

Professor V.Stebliuk, the chairman of Rehabilitation Committee of ATO Victims of the Ukrainian Association of Physical and Rehabilitation Medicine, noted that there was no such medical specialty as "medical rehabilitation" in Ukraine [8]. According to the provided information, the available specialties correspond to the needs of departments and research_institutes, as approved of by the Ministry of Health. However, this particular medical specialty does not exist. As Professor V. Stebliuk further added, this was the reason why physiotherapists, neurologists, traumatologists and all relevant specialties should be involved in rehabilitation. Specialists in physical rehabilitation were taught in the direction of training "physical education and sport" at pedagogical universities or universities of sports and physical education. However, they could not work at departments of medical institutions as the official requirement for running such institutions does not require such experts. Consequently, as the personal documents of these professionals indicate, they would work as massage nurses.

The issue of providing rehabilitation and specialists in Ukraine began to be raised in 2005, when the legal act "About Rehabilitation of the Disabled" was adopted. At the time of its adoption, the law was rather progressive, as it proposed an integral legal and regulatory mechanism for regulating relations and processes in the field of rehabilitation of the disabled.

In April 2015, the Committee of Health Care at Verkhovna Rada of Ukraine created a Coordination Council for Rehabilitation under the chairmanship of People's Deputy Iryna Sysojenko [9]. The main aim of the Council was to write a project of law on rehabilitation, which would ensure effective rehabilitation not only for the disabled, but also for everyone else who needs it.

The project was criticized as it was considered as non-reformist and one that duplicates solutions already approved by the current law about "rehabilitation of the disabled", which are presented in a different order or partially changed. In addition, the principles of work and responsibilities of the multidisciplinary team in medical and rehabilitation institutions were not prescribed in it.

Another group of authors recently proposed an alternative law project [8]. It states that the organization of the rehabilitation process should rely on other than post-Soviet principles, on modern ones:

- the International Classification of Functioning (in spite of the Medical International Classification of Diseases, does not determine the presence of the disease, but the entire range of consequences that this disease causes, as well as the presence or absence of a person's real opportunities to serve themselves);

- new specialties, which are currently absent in Ukraine: doctor of physical and rehabilitation medicine, physical therapist, ergotherapist, etc.;

- the rule that the key participant in the rehabilitation process is the patient;

- the statement that rehabilitation should be carried out by a multidisciplinary team;

- the fact that it is necessary to change public administration in the field of health care, etc.

To understand the scope of the issue, one should know that there are 25,000 physical therapists and 9,000 ergotherapists in Canada with its population of 35 million, whereas there are 160 physical therapists in Ukraine and two ergotherapists certified abroad $[9,10]$.

Thus, if one asks whether there are physiotherapists in Ukraine, the answer is positive. However, these are doctors who prescribe some medications or_natural medicine in the treatment of patients, whereas abroad, these are specialists who are engaged in the restoration of patients' movements.

In order to reform the system of rehabilitation medicine in Ukraine, a proper length of time should be allocated as the process will last longer than a year or two. It is understood by Andriy Turchyn, the Deputy Chief Doctor of Outpatient and Diagnostic Assistance to the Kyiv Regional Clinical Hospital [10]. In addition, legislative resolution of rehabilitation issues also requires a separate solution. "First, there should be a legislative framework: the definition of protocols for rehabilitation of patients with those or other diseases, injuries, operations. The training of specialists should also be considered but not before the system of training is established. Also, the material base seems crucial. The rehabilitation department should be equipped accordingly ", - he remarks. By using modern techniques, patients may become functional in the first days after surgical interventions. Therefore, obsolete approaches to rehabilitation should be changed so that patients are more likely to adapt to social life after serious injuries or illnesses.

Ukraine has started to create a modern system of rehabilitation actively [8,10]. Since August 2016, the National Classification of Occupations has given new names to professions, including: a doctor of physical and rehabilitation medicine, an ergotherapist and a physical therapist. In November 2016, the Ministry of Healthcare 
has already approved of the qualifications for these professions. The current regulatory framework is being reorganized so as to create jobs in health care facilities for specialists in medical and physical rehabilitation. The Ministry of Healthcare of Ukraine initiated the implementation of the International Classification of Functioning, Disability and Health in the Ukrainian rehabilitation. The current legislation is based on the socalled International Classification for Patient Safety. It was proposed in 1989, but was not approved by the World Health Organization. Since 2001, there is an international classification of the functioning, disability and health in the world, on which the system of rehabilitation is under construction. On December 15, 2016, Uliana Suprun, the Minister of Health, signed a separate mandate for the implementation of this classification. The WHO representatives will conduct trainings on the classification for Ukrainian specialists. At the first stage, they will inform them about the system and the way it is used.

Already, nine scientific research institutions, 11 specialized departments in higher undergraduate education institutions and 3 departments in postgraduate education institutions in Ukraine [2] are engaged in the development of scientific programmes, rehabilitation protocols, and methodological guidelines for rehabilitation institutions.

To facilitate the reforms of the system of rehabilitation in Ukraine, the Ministry of Healthcare plans to rebuild some healthcare facilities in rehabilitation structures and implement rehabilitation centres throughout the country so that the reform has a systemic effect. In fact, modern rehabilitation centres have already been set up in Kyiv, Lviv, Rivne and other regions; these centres employ qualified medical and physical rehabilitation specialists and have proper facilities designs with appropriate wide corridors, doors, equipped shower cabins, equipment, etc. $[11,12,13]$.

Particular attention is now paid to rehabilitating ATO soldiers. Nowadays, the state provides disabled warriors with dentures. As it is reported, modern prosthesis costs about 20 thousand euro, and the Ukrainian government is ready to pay such money [2]. Experienced prosthetics and orthopedists from the UK are ready to introduce Ukrainian doctors into innovative prosthetic technologies. British specialists have developed prosthesis that can change disabled people's life by providing maximum of comfort. These people will be able to walk more quickly, and will have an opportunity to climb and descend stairs. At present, the best that an artificial knee joints in Ukraine can offer is maintaining a person's balance so that it allows him/her to keep own weight. However, it is a huge drawback, because it does not prevent a person from falling if a mistake is made said D. Boender, the producer of the knee joint Very Good Knee, which today is sold by the British Orthomobility Ltd. According to him, the joint produced by him allows the person to keep a proper position, until he/she makes a step. When the patient rests on the other leg, the joint of the supporting leg becomes flexible, which makes taking the next step easy [2].

Ukraine is beginning to actively engage in new approaches to rehabilitation now, and it is hoped that once it is introduced it is going to enhance the quality of life of the disabled.

\section{Conclusions}

1. The System of Rehabilitation is ineffective in Ukraine.

2. It is absolutely necessary to provide reformation of Rehabilitation System according to the International standards.

3. The most important expected results of the reform on the rehabilitation system in Ukraine include:

- increasing the life expectancy and quality of life in the population;

- reducing the number of cases of complications caused by diseases;

- reducing the number of cases of disability and mortality;

- reducing the level of primary outflow of disability (first of all patients of working age) as a result of complications.

\section{References:}

1. The Concept of the State Target Program “Medical Rehabilitation" for 2011-2015 [Internet]. 2010. Available from: http://www.moz.gov.ua/ua/print/Pro_20100404_0.html.

2. Potiha A. Socio-psychological and medical rehabilitation of ATO participants [Internet]. 2015 ; [about 1 p.]. Available from: http://nbuviap.gov.ua/index.php?option=com_content\&view=article\&id=858:reabilitatsi ya-uchasnikiv-ato \& catid=8\&Itemid $=350$.

3. Chopak O. Problems of adaptation and rehabilitation of those who visited ATO [Internet]. 2014 Oct[cited 2014 Oct 21]; [about 1 p.]. Available from: http://karpatskijobjektiv.com/problemi-adaptaciyi-ta-reabilitaciyi-tixxto-pobuvav-v-atoproblemi-adaptaciyi-ta-reabilitaciyi-tix-xto-projshov-vijnu/. 
4. About carrying out measures on social adaptation and psychological support of Ukrainian soldiers participants of the antiterrorist operation in eastern Ukraine and their families [Internet]. 2015 Aug[cited 2015 Aug 07]; [about 3 p.]. Available from: http://svyat.kievcity.gov.ua/news/14951.html.

5. INSIDER. Rehabilitation: "peaceful" problems of the Ukrainian military [Internet]. 2015 Jun[cited 2015 Jun 09]; [about 2 p.]. Available from: http://www.theinsider.ua/lifestyle/5576ead12a080/.

6. Moisieeva T. Rehabilitation: Restart [Internet]. 2017 Mar [cited 2017 Mar 18]; [about 2 p.]. Available from: https://ukurier.gov.ua/uk/articles/reabilitaciya-perezavantazhennya/.

7. Zaretska N, Golik V. Rehabilitation reform in Ukraine should not remain disabled [Internet]. 2016 Jun[cited 2016 Jun 04]; [about 1 p.]. Available from: https://dt.ua/HEALTH/reforma-reabilitaciyi-v-ukrayini-nepovinna-zalishitis-invalidom-_.html.

8. Golyk V. "We strive to make the apartment not a prison for a handicapped person" [Internet]. 2017 Feb[cited 2017 Feb 07]; [about 4 p.]. Available from: https://ukr.lb.ua/society/2017/02/07/357816_volodimir_golik_ mi_pragnemo_shchob.html.

9. Sysoenko I. Rehabilitation system in Ukraine to be! [Internet]. 2016 Mar [cited 2016 Mar 18]; [about 1 p.]. Available from: http:// www.pravda.com.ua/columns/2016/03/18/7102574/.

10. Shvydko A. MOH announces the reform of rehabilitation medicine in Ukraine [Internet]. 2017 Feb[cited 2017 Feb 06]; [about 1 p.]. Available from: https://www.radiosvoboda.org/a/28281168.html.

11. National Assembly of People with Disabilities in Ukraine. At the Center for Psychological Rehabilitation and Treatment of ATO Participants, the Psychologically-Social Rehabilitation Service was opened [Internet]. 2015 Jan [cited 2015Jan 29]; [about1 p.]. Available from: http://naiu.org.ua/u-tsentri-psyholohichnoji-reabilitatsijii-likuvannya-uchasnykiv-ato-zapratsyuvala-sluzhba-psyholohichno-sotsialnoho-vidnovlennya/.

12. Vashe Zdorovja. Doctors in the war - how to ensure the readiness of "Number one"? [Internet]. 2014 Sep [cited 2014 Sep 05]; [about 2 p.]. Available from: http://www.vz.kiev.ua/mediki-na-vijni-yak-zabezpechitigotovnist-nomer-odin/.

13. Baglay I. A rehabilitation center for ATO participants was opened in Kyiv [Internet]. 2016 Nov [cited 2017 Nov 17]; [about 1 p.]. Available from: http://podrobnosti.ua/2144621-u-kiv-vdkrili-tsentr-reabltats-uchasnikvato.html. 